\title{
THE ORIVESI GRANITE BATHOLITH, SOUTHERN CENTRAL FINLAND - CHARACTERISTICS AND EMPLACEMENT
}

\author{
OLAVI SELONEN and CARL EHLERS
}

OLAVI SELONEN and CARL EHLERS 1996. The Orivesi granite batholith, Southern Central Finland - characteristics and emplacement. Bull. Geol. Soc. Finland 68, Part 1, 11-24.

The Orivesi granite batholith is situated in an E-W trending belt of granite intrusions along the southern margin of the Central Finland Granitoid Complex (CFGC). It consists of the dominant Orivesi granite and of two minor components: a coarse-grained quartz-rich porphyritic granite (the Särkijärvi granite) and an aplite granite. No associated mafic components are found. The Orivesi granite is light red to red, coarse-grained and porphyritic with a magmatic foliation. The porphyritic texture is formed by potassium feldspar phenocrysts, which are in general euhedral, but oval (and mantled) megacrysts occur. The granite is extracted as dimensional stone ("Cardinal Red"/"Crystal Rose") from the southwestern part of the batholith. Additional potential sites for dimension stone are identified in same part of the batholith.

The Orivesi granite batholith has intruded along regional shear zones in the southern part of the CFGC. The intrusion was diapiric at least during the final emplacement, and produced the magmatic structures in the batholith. Regional deformation has affected the batholith only as semi-brittle movements along aplites and narrow shear bands. The magmatic foliation is concentric in relation to the margins of the batholith. The ductile structures in the host rocks are parallel to the long axis of the batholith and do not continue into its marginal parts. The Orivesi granite is intrusive against both the surrounding granodiorites and the mica schists and can be regarded as post-tectonic in relation to the ductile deformation in the host rocks.

A NNW-SSE trending fault zone cuts the Orivesi granite batholith into two halves. The western half has been uplifted in relation to the eastern half producing different structural features in the batholith halves at the present level of erosion. A section representing a lower crustal level, the western half, consists of sparsely fractured Orivesi granite with well developed, steep, penetrative and concentric foliation. The upper parts of the batholith in the eastern half, on the contrary, are characterized by intrusions of late magmatic melts in the Orivesi granite: the Särkijärvi granite and the aplite sheets and dykes. The foliation in the Orivesi granite is poorly developed in the eastern half and the late fracturing on outcrop scale is dense. In consequence the quarries and potential sites of dimension stone are in the western half, where the Orivesi granite is as dimension stone material more homogeneous and sound.

Key words: granites, batholiths, emplacement, diapirism, shear zones, faults, structural analysis, complexes, igneous rocks, dimension stone, Palaeoproterozoic, Orivesi, Juupajoki, Finland.

Olavi Selonen and Carl Ehlers: Åbo Akademi University, Department of geology and mineralogy, FIN-20500 Turku, Finland.E-mail: olavi.selonen@abo.fi; carl.ehlers@abo.fi 


\section{INTRODUCTION}

The Central Finland Granitoid Complex (CFGC) (fig. 1) is a large segment of Palaeoproterozoic Svecofennian crust consisting mostly of granites, but also comprising intrusions ranging in composition from gabbro to granite. The granitoids show mainly I-type chemical characteristics and calk-alkaline affinities. The plutons in the CFGC can vary considerably in size and structure. Large areas consist of homogeneous intrusive rocks, while other regions can include composite plutons associated with different intrusive components and dyke rocks. The granitoids are often medium- to coarse-grained rocks with a porphyritic texture made up of large K-feldspar megacrysts (Nironen \& Csongrádi 1984; Nurmi et al. 1984; Nurmi \& Haapala 1986; Front \& Nurmi 1987; Nironen \& Front 1992).

The granitoids in the CFGC show Ub-P zircon ages of 1890-1870 Ma (Aho 1979; Nurmi et al. 1984; Huhma 1986; Patchett \& Kouvo 1986;
Sjöblom 1990; Nironen \& Front 1992). They are described as synkinematic or synorogenic and emplaced during the Svecofennian orogeny (eg. Nurmi \& Haapala 1986; Front \& Nurmi 1987). Despite their similarity in radiometric ages, the CFGC-granitoids show different degrees of deformation and different types of contacts against the host rocks. For example, Sjöblom (1990) describes cross-cutting contacts between the Juupajoki granite batholith and the host rocks in the southern part of the CFGC indicating a post-tectonic character for the granite (see also Laitakari 1986). Rämö \& Nironen (1995) distinguish a $\sim 1.87$ Ga old posttectonic suite of granites in the southern parts of the CFGC. Lahtinen (1994) connects the granitoids to different collisional/post-collisional stages and periods of magmatism during the crustal evolution of the Svecofennian domain. Korja (1995) implies that the synkinematic granitoids could be post-collisional in relation to the main stacking episode (or growth period) of the Svecofennian orogeny.

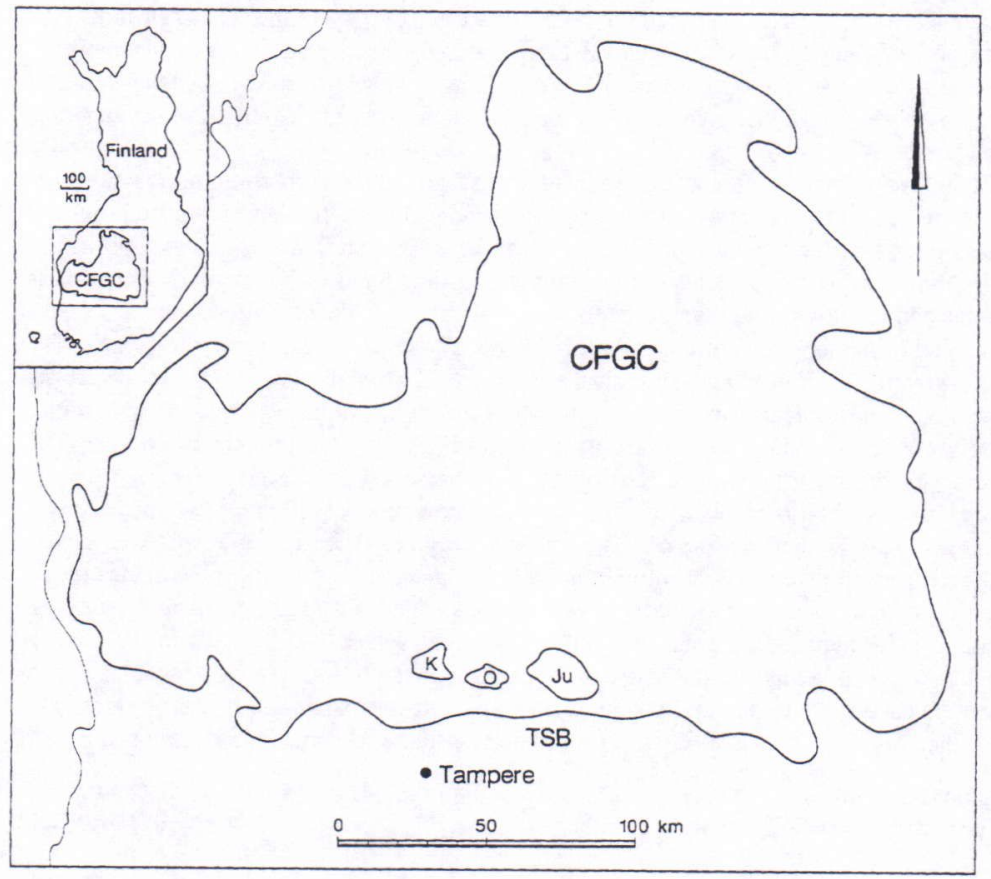

Figure 1. Location of the Central Finland Granitoid Complex (CFGC). The granitoids at the southern margin of the CFGC are Kuru $(K)$, Orivesi $(O)$ and Juupajoki $(J u)$. TSB=Tampere Schist Belt. Modified after Simonen (1980). 
Structural studies and investigations regarding the emplacement of various granitoids in Finland are few and include Kallio (1983), Ehlers \& Bergman (1984), Bergman (1986), Nironen (1989), Nironen \& Bateman (1989) and Nironen (1995). We shall exemplify the problems with the case of the Orivesi granite batholith in the southern part of the CFGC. The Orivesi granite is extracted as dimensional stone in the southwestern part of the batholith under the commercial names of "Cardinal Red" and "Crystal Rose". The batholith has been one of the study objects in our ongoing project "Exploration of dimension stone - geological aspects" financed by the K.H. Renlund Foundation (see Selonen 1991; 1994). Our goal is to identify geological factors crucial for the formation of rock portions suitable for the extraction of dimension stone. In this paper we will analyse the geological setting and the structures in the Orivesi granite batholith and discuss the emplacement of the batholith. The paper is based on field observations made by the first author.

\section{GENERAL OUTLINE AND HOST ROCKS}

The Orivesi granite batholith covers an area of $\sim 100 \mathrm{~km}^{2}$ at the southern margin of the CFGC (fig. 1), between the Juupajoki and Kuru granite batholiths in a conspicuous $60-70$ kilometrelong east-west trending belt of granites (see eg. Simonen 1980). The Orivesi granite batholith consists of three intrusive components, one of which, the Orivesi granite, builds up the bulk of the batholith. The batholith and the CFGC are in the south bordered by the Tampere Schist Belt (fig. 1).

There is no previous detailed studies of the Orivesi granite batholith. The area has been mapped by Laitakari (1986). The adjacent Juupajoki granite batholith has been briefly discussed by Sjöblom (1990) and Lahtinen (1994). The potential for dimension stone in Juupajoki and Orivesi batholiths has been evaluated by Selonen (1991). K-rich granitoids in the southern part of the CFGC have been described by Rämö \& Nironen (1995). Aurola (1967) has investigated the Kuru granite batholith focusing on dimension stone geology.
The structural setting of the granitoids in the southeastern part of the CFGC has been studied by Kallio (1983) and Nironen (1995).

No age determinations are available for the Orivesi granite batholith. The porphyritic granite in Juupajoki (Koppelojärvi) has Ub-P zircon ages of $1879 \pm 14 \mathrm{Ma}$ (Patchett \& Kouvo 1986) and $1880 \pm 16 \mathrm{Ma}$ (Sjöblom 1990). The Puula granite in the SE parts of the CFGC shows an age of $1876 \pm 7$ Ma (Nironen 1995). The Lehesvuori granite in Jyväskylä and the Keuruu granodiorite in the CFGC, but north of the Orivesi and Juupajoki granites, yield ages of $1889 \pm 15 \mathrm{Ma}$ and $1883 \pm 14$ Ma, respectively (Huhma 1986). The porphyritic granodiorite in Joutsa (SE part of the CFGC) shows an age of 1892 $\pm 3 \mathrm{Ma}$ (Kallio 1986).

The Orivesi granite batholith is enclosed by mica schists, gabbros, diorites, granodiorites and tonalites (quartz diorites in Laitakari 1986). Pelitic mica schists occur as a couple of southwest-northeast striking narrow zones east of the batholith and as a broader east-west trending zone south of the batholith. The mica schists are in places intercalated with quartz-feldspar schists and volcanic rocks. Primary sedimentary structures, such as graded bedding, have been preserved in the schists. The schistosity is steeply dipping.

The schists are intruded and enclosed by gabbros, diorites, granodiorites and tonalites. The gabbro and the diorite occur as small bodies in the northeastern and western parts of the area. They are dark, medium and even-grained, massive or foliated. The most widespread host rocks are grey, medium and evengrained granodiorites and tonalites with foliation and diffuse internal contacts. They occupy the northern part of the study area and large areas further north. They contain scattered megacrysts of potassium feldspar and abundant mafic inclusions, which are found all over the area. Henceforth we collectively call these rocks granodiorites. Along the western and the northnortheastern margins of the Orivesi granite batholith, presumably in contact with the batholith, there is a medium-grained porphyritic granite with potassium feldspar megacrysts but, in contrast to the Orivesi granite, it contains mafic inclusions. This rock has not been included in the batholith as defined here. 
Front \& Nurmi (1987) have proposed multistage origins for the synkinematic granitoids with mafic inclusions, including the mixing of mantlederived and crustal material, partial melting of the crust and the formation of granitoid magmas. The protolith of the granitoids was interpreted to include mainly igneous crustal rocks. Accordingly, we interpret the mafic inclusions in the granodiorite as components in a mixing/mingling system, and include the medium-grained granites as parts of same magma mixing/mingling system.

An occurrence of orbicular granite (in the centre of the batholith) and some subjotnian diabase dykes can also be found in the area. For the host rocks see also Laitakari (1986) and fig. 2.

\section{MAGMATIC COMPONENTS}

The Orivesi granite batholith as defined in this paper includes three magmatic components: the
Orivesi granite, the Särkijärvi granite and the aplite granite. Aplite and pegmatite dykes also occur in the area.

The light red to red, coarse-grained and porphyritic Orivesi granite occupies almost the whole area of the batholith (fig. 2). Its main minerals are potassium feldspar, quartz, plagioclase, biotite and hornblende. The porphyritic texture is formed by potassium feldspar phenocrysts $1-7 \mathrm{~cm}$ long and $0.5-3 \mathrm{~cm}$ wide. The megacrysts occur very close together. They are red or light red and often euhedral. Also round and oval crystals can be found, the diameter of which can be up to $5 \mathrm{~cm}$. Some grains are mantled by plagioclase. Towards the contacts against the host rocks, the grains become smaller in size.

In the central-eastern parts of the Orivesi granite batholith, there is a porphyritic blue-grey granite, the Särkijärvi granite, occurring as irregularly shaped bodies (fig. 2). It differs from the Orivesi granite by its higher quartz content, and by its

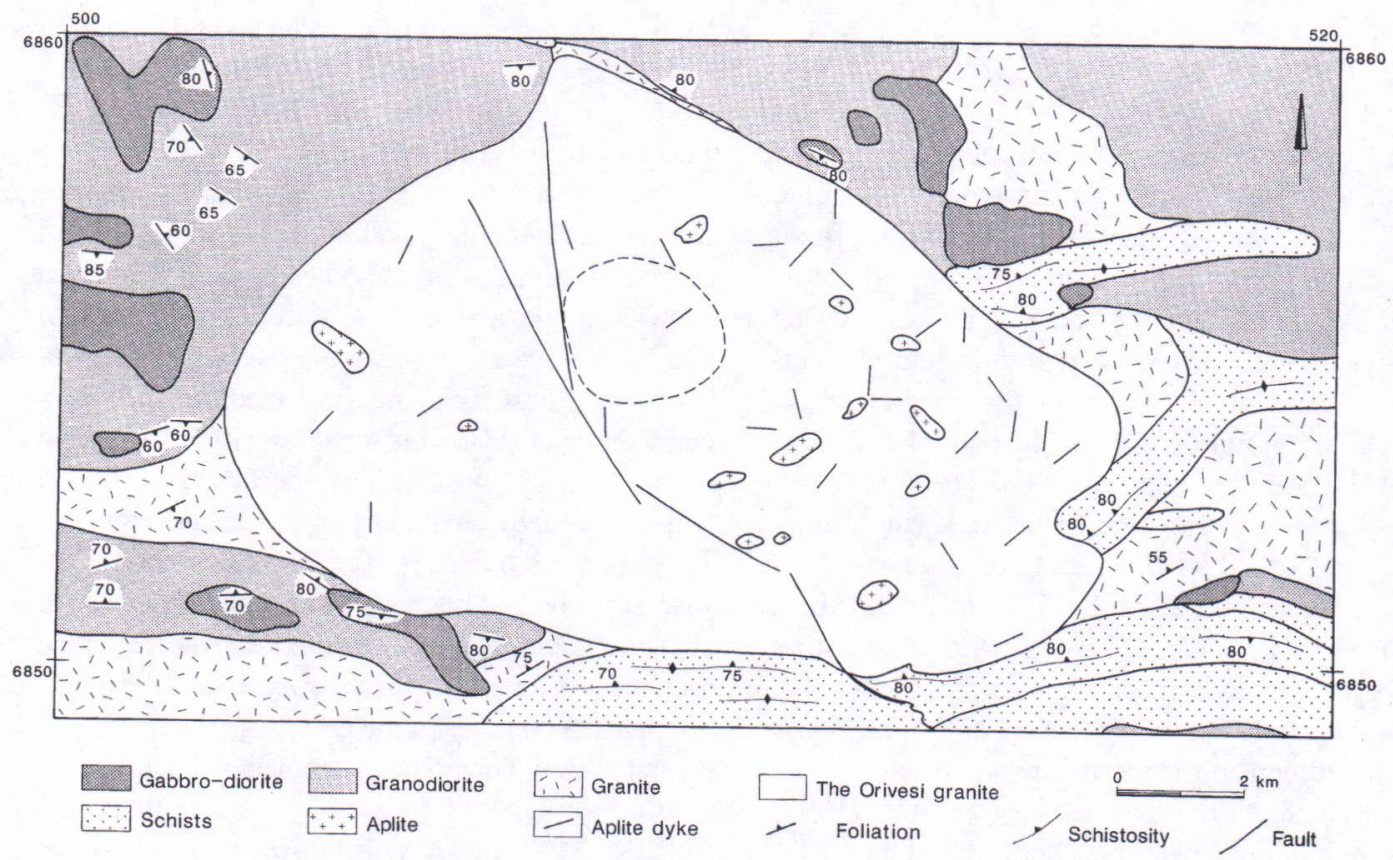

Figure 2. Geological map of the Orivesi granite batholith. The Särkijärvi granite occurs as scattered bodies inside the dotted circle in the central-eastern parts of the batholith. The map is based on field observations by the first author and on Laitakari (1986). 
smaller and more scattered potassium feldspar megacrysts. The Särkijärvi granite grades in places into a porphyritic fine-grained granite with occasional larger potassium feldspar megacrysts (1$3 \times 2-4 \mathrm{~cm})$ or with abundant small scattered potassium feldspar grains $(0.5 \times 0.5 \mathrm{~cm})$. The main minerals in the Särkijärvi granite are potassium feldspar, quartz, plagioclase and biotite. The contacts against the Orivesi granite are poorly exposed and diffuse; no sharp contacts between the rocks are found. Its position within the batholith, the contacts and the quartz-rich character of the Särkijärvi granite indicate that it is younger than the Orivesi granite and represents a product of a residual magma.

Aplite granite is found as small roundish or irregular bodies mainly in the eastern parts of the batholith (fig. 2). The aplite granite is light red to grey, homogeneous, foliated and in places sheared. It is porphyritic and contains euhedral potassium feldspar megacrysts, which are occasionally aligned in the direction of the foliation. The Kfeldspar phenocrysts can have a bimodal size distribution with mixed smaller and larger grains. The main minerals of the aplite granite are quartz, plagioclase, potassium feldspar and biotite. The contacts against the Orivesi granite are distinct, but not as sharp as in the case of the aplite dykes. In general they dip steeply, but flat-lying contacts also occur. The aplite is both concordant with and cross-cutting against the foliation of the granite. The Orivesi granite batholith contains abundant aplite dykes varying in width from $\sim 50 \mathrm{~cm}$ down to a few centimetres (fig. 2). The aplite dykes are much more abundant in the eastern parts of the batholith than in the western parts. Some of the dykes are strongly sheared, indicating tectonic movements coeval with their emplacement. Similar aplite dykes also occur outside the batholith cutting across the host rocks. Most of the dykes are subvertical, their contacts against the Orivesi granite are sharp-edged and they cut the foliation of the granite. We interpret the irregular aplite patches as subhorizontal sheet-like intrusions, coeval with the steep dykes.

Pegmatite dykes are also observed, but they are fewer in number than the aplite dykes. The aplite sheets and pegmatite dykes conceivably represent a brittle late fracturing and subsequent filling of the fractures with late magmatic melts.

No mafic intrusives are associated with the Orivesi granite batholith.

\section{INCLUSIONS}

The Orivesi granite is generally poor in inclusions. Mafic inclusions, common in the surrounding granodiorite, are not observed in the Orivesi granite, indicating that the granite represents a later pulse of magma in relation to the granodiorite. According to Lahtinen (1994) the origin of the high-K granites with tholeiitic features in the southern part of the CFGC, eg. the Juupajoki granite, can be attributed to melting of rocks with WPB affinities at the base of the crust.

Sparse small lens-shaped dark inclusions, eg. $7 \times 26 \mathrm{~cm}$ on outcrop, can be found in the Orivesi granite elongated in the direction of the foliation. Their main minerals are hornblende, biotite, quartz, plagioclase and sphene. They commonly include megacrysts of potassium feldspar. Schlierens rich in biotite, hornblende and opaques occur in the Orivesi granite (eg. in the SW part of the batholith).

Two types of felsic medium-grained granitic inclusions occur sparsely in the southern parts of the Orivesi granite. They can be roundish and large with sizes in the order of metres, or smaller flattened lenses (some centimetres long) elongated in the direction of the foliation. The inclusions have a mafic margin against the Orivesi granite. The main minerals are potassium feldspar (also as megacrysts), quartz, plagioclase, biotite and hornblende.

Xenoliths of the host rocks can in places be found in the Orivesi granite. The edges of the xenoliths are often rounded and they are aligned parallel to the foliation. Angular xenoliths can occasionally be observed, eg. in the southern parts. In the eastern parts of the batholith, gently dipping deformed mica schist xenoliths are found. These mica schist xenoliths, in contrast to the steeply dipping schists surrounding the batholith, dip gently $20^{\circ}-50^{\circ}$ inwards, towards the centre of the batholith. 
Small lens-shaped felsic inclusions are occasionally observed in the Särkijärvi granite. Fragments of Orivesi granite occur in the aplite granite.

\section{CONTACTS}

The contacts between the Orivesi granite batholith and the host rocks are poorly exposed. The western and the northern contacts against the medium-grained porphyritic granite, the northwestern contact against the granodiorite and the eastern contact against the mica schist zones are not exposed. This is also the case in the south against the supracrustals; however, the contact zone can be observed.

The contact zone against the supracrustals in the south: the Orivesi granite is intensely foliated at the contact. The steep schistosity in the mica schists is parallel to the foliation in the granite. The grain size of the granite is reduced towards the contact and the potassium feldspar phenocrysts become more sparse. The granite becomes enriched in biotite and the colour is more bluish near the contact. Xenoliths of schists with different degrees of assimilation can be found in the granite. The contact zone is rich in aplite and pegmatite dykes, which also cut the surrounding schists. The contact strikes roughly east-west and dips $\sim 60^{\circ}$ inwards (northwards). The mica schist is rich in granitic veins near the contact and resembles a veined gneiss. Some of the veins are porphyritic and cut the schistosity in the schists. Away from the contact the veins decrease in number. The leucosome in the mica schists often contains scattered potassium feldspar megacrysts.

The contact against the infracrustals in the northeast: the Orivesi granite is intensely foliated. The steep foliation in the surrounding granodiorite is parallel to that of the granite. The contact strikes NW-SE and dips steeply. The granodiorite contains small mafic inclusions, which are absent in the Orivesi granite. Xenoliths of granodiorite occur in the granite in the direction of the foliation. Dark dioritic xenoliths also occur in the Orivesi granite. The granodiorite is porphyritic and has potassium feldspar megacrysts at the contact. A fine-grained granite with xenolites of granodiorite occur in abundance along the contact. The contact is rectilinear and coincides with a NW-SE directed fault/fracture zone suggesting a tectonic control for the emplacement of the batholith (fig. 5).

The contact against the infracrustals in the southwest: towards the contact, patches of dark minerals and small assimilated xenoliths of granodiorite appear in the Orivesi granite. Closer to the contact the granite contains more dark patches and the potassium feldspar megacrysts become smaller in size. At the contact there is a hydrid-like granitoid with small mafic inclusions and megacrysts of potassium feldspar. In places it seems as if the Orivesi granite brecciates the hybridic rock. The hydrid rock grades into a grey non-porphyritic granodiorite.

\section{STRUCTURAL FEATURES IN AND AROUND THE ORIVESI GRANITE BATHOLITH}

On the map the Orivesi granite batholith is slightly oval-shaped in an east-west direction (fig. 2). The batholith is roundish, but the northeastern contact is rectilinear following a fracture/fault zone. The batholith is cut into two halves by a younger NNW-SSE trending fault zone (fig. 2). The halves have different structural features.

The eastern half of the batholith is slightly larger in diameter than the western half, which can best be observed in the northern parts of the batholith (fig. 2). The magmatic components are unevenly distributed inside the batholith. Scattered bodies of Särkijärvi granite occur in the centraleastern parts. The aplite sheets occur mainly in the eastern half of the batholith, forming a structure roughly concentric with its eastern margin. Most of the aplite dykes are also in the eastern half. Some of the dykes are at a high angle to the eastern contact of the batholith, but do not form a discernible radial pattern (fig. 2). The western half of the batholith consists chiefly of the Orivesi granite.

The penetrative foliation in the Orivesi granite is defined by the parallellism of potassium feldspar phenocrysts and biotite grains. Particularly in the 
western half the foliation is concentric and concordant with the contacts of the batholith (fig. 3). In the eastern half, the foliation is poorly developed with less consistent directions. The intensity of the foliation generally increases against the margins. In outcrops it can be more variable and in places the granite can be quite massive, implying movements in the magma. The foliation dips $60^{\circ}-90^{\circ}$ towards the centre of the batholith (fig. 3 ) indicating a funnel-like 3D shape for the batholith. In the eastern half of the batholith concordant schist inclusions dip $50^{\circ}$ towards the centre and have a more gentle dip $\left(20^{\circ}\right)$ closer to the margin. The Orivesi granite has in places (eg. in the SW parts of the batholith), a weakly developed subvertical lineation defined by the long axes of potassium feldspar phenocrysts. The texture of the Orivesi granite is thus of S-/L<S-type (Flinn 1965). No pronounced lineation has been mapped in the host rocks outside the batholith (see also Laitakari 1986). Narrow $(<1 \mathrm{~cm})$ shear bands are observed in the Orivesi granite, indicating post-crystallisation tectonic movements.
The surrounding supracrustal host rocks show a dominant schistosity (S1), which overprints the primary bedding (S0). F1 folds with well developed axial plane schistosity and flat-lying fold axes are associated with the main S1 schistosity. S1 is refolded by F2. The schistosity in the host rocks has not been observed to continue across the contacts into the marginal parts of the Orivesi granite batholith.

\section{Regional and local fractures}

It can be deduced from aeromagnetic shaded relief maps, topographical maps and from the map of surficial deposits (Kujansuu et al. 1981) that the Orivesi granite batholith, as well as the Juupajoki and Kuru batholiths, are bordered by regional NW-SE trending lineaments in the scale of tens of kilometres (fig. 4). The batholiths occur at the SE-end of the zone of lineaments. Interpretation of topographical maps and the map of surficial deposits (Kujansuu et al. 1981)

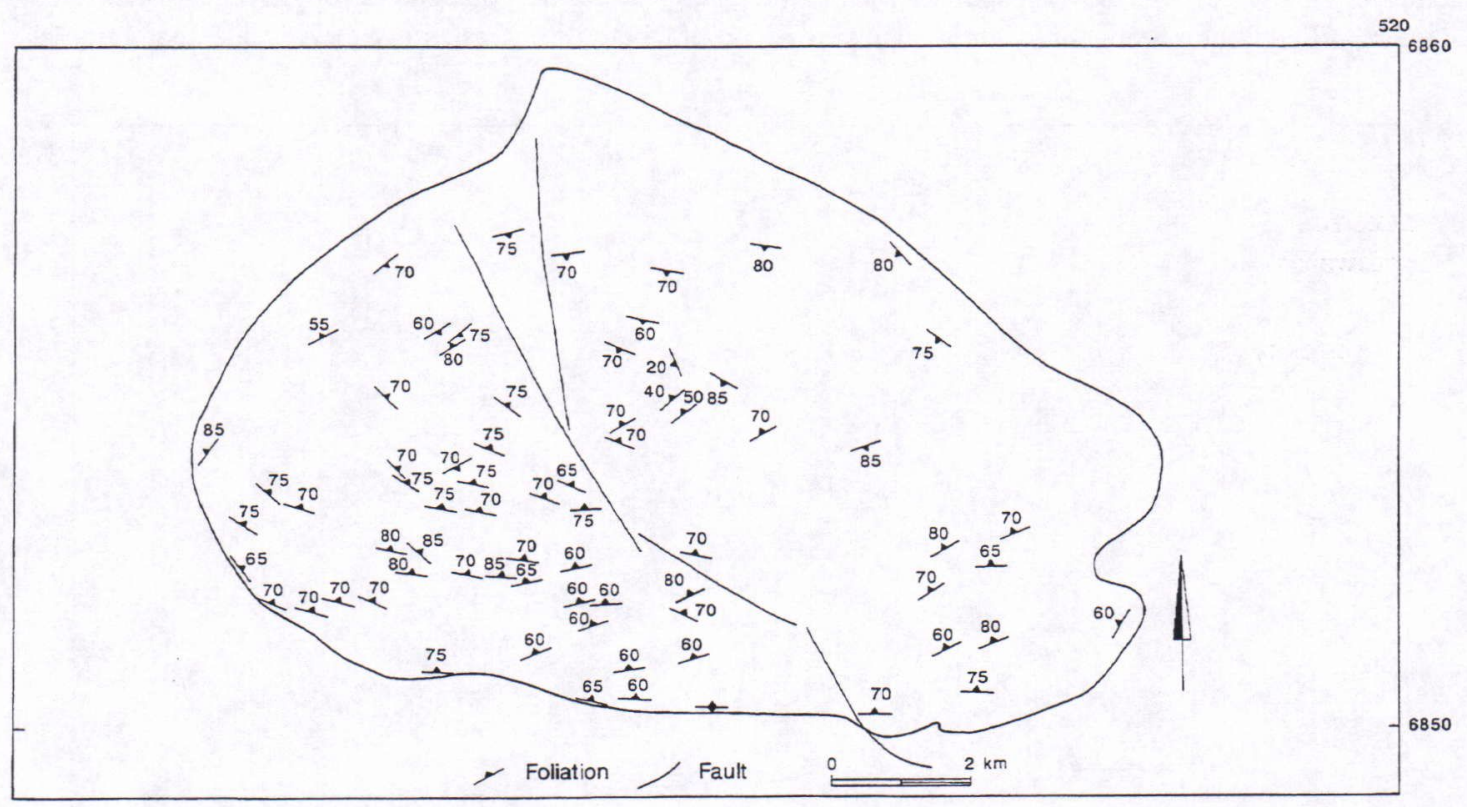

Figure 3. The magmatic foliation in the Orivesi granite batholith is defined by the preferred orientation of potassium feldspar phenocrysts and biotite grains. The concentric foliation is better developed in the western half of the batholith than in the eastern half. The map is based on field observations by the first author and on Laitakari (1986). 
indicate that major fracture zones occur in the same NW-SE direction, transecting the batholith (fig. 5). In the southern part of the area the lineaments and the fracture zones curve towards the east. A pattern of local kilometre-scale fracture zones confined to the Orivesi batholith is discernible on the topographical maps (fig. 5). In the southwestern parts of the batholith these zones occur at high angles to the contacts of the batholith (fig. 5). The fracturing in the Orivesi granite in outcrops is more dense in the eastern half of the batholith than in the western half (Selonen 1991).

The two halves of the Orivesi batholith are separated by a large zone of fractures. A part of this fracture zone is exposed in the northern-central parts of the batholith; it is a $400 \mathrm{~m}$ long and $\sim 10$ $\mathrm{m}$ wide zone of crushed Orivesi granite. A sheared aplite with subvertical streching lineation (elongated aggregates and crystals of quartz) also occurs along the zone. These rocks are cut by subhorizontal and subvertical (dip mainly of $0^{\circ}-40^{\circ}$ ) quartzfilled fractures (from $20 \mathrm{~cm}$ down to some centimetres in width) in several generations. The quartz-filled fractures are cut by narrow subvertical and subhorizontal shear bands (from $5 \mathrm{~cm}$ down to less than $1 \mathrm{~cm}$ wide). A fully cataclastic rock can also be found in the fault zone. The deformed aplite indicates ductile shearing, while the quartz veins and the shear bands indicate brittle behaviour. These fault rocks cannot be found south of the fracture zone. In the continuation of the zone towards the north the bedrock is poorly exposed and covered by a large bog. A similar zone of crushed rocks can be found along the northeastern contact of the Orivesi granite batholith.

\section{STRUCTURAL INTERPRETATION AND EMPLACEMENT OF THE ORIVESI GRANITE BATHOLITH}

The structural differences between the two batholith halves of the Orivesi granite batholith are emphasized in fig. 6A.

The western half is more intensely foliated than the eastern half and the foliation is penetrative, concentric and dips steeply towards the centre of the batholith, representing roughly the "waist" area of a batholith (Castro 1987). A weak steep mineral

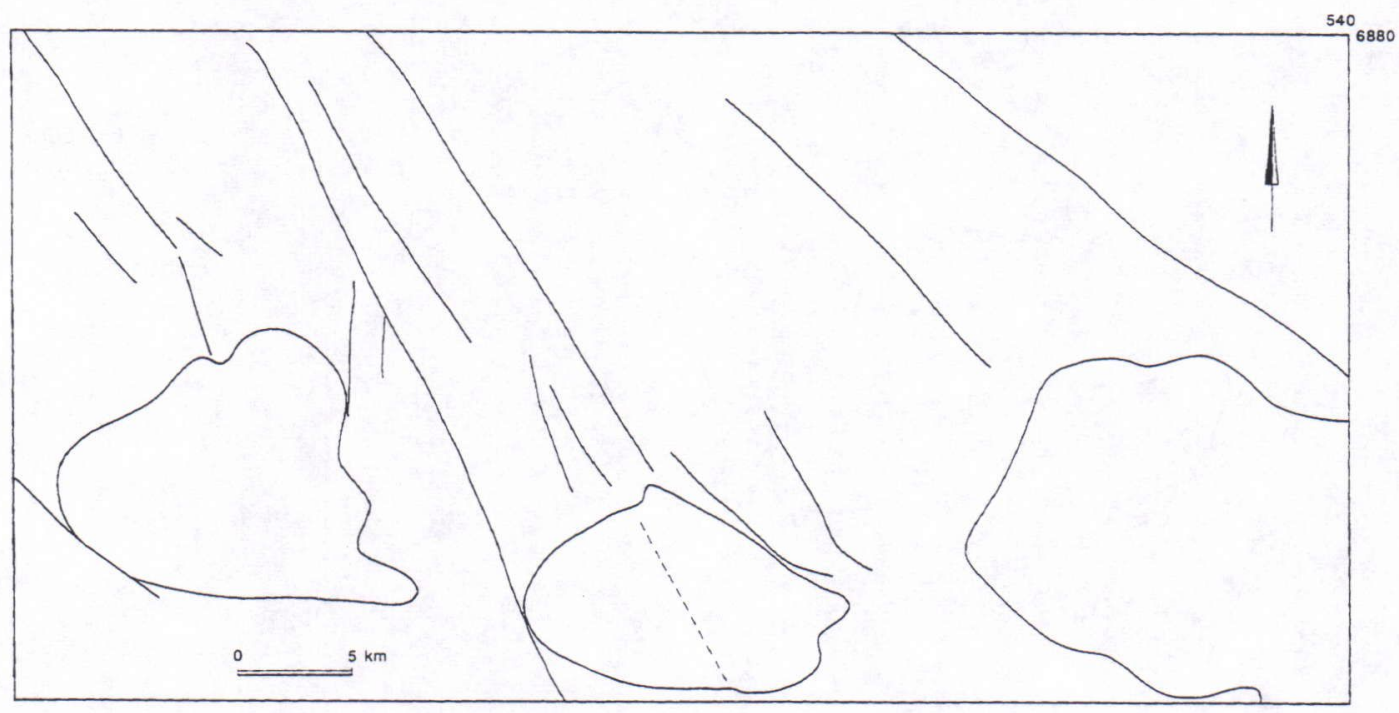

Figure 4. Regional lineaments in the southern parts of the CFGC. The lineaments are interpreted from aeromagnetic shaded maps, topographical maps, the map of surficial deposits (Kujansuu et al. 1981), Laitakari (1986) and Sjöblom (1990). The granitoids from the west are Kuru, Orivesi and Juupajoki (cf. fig. 1). 


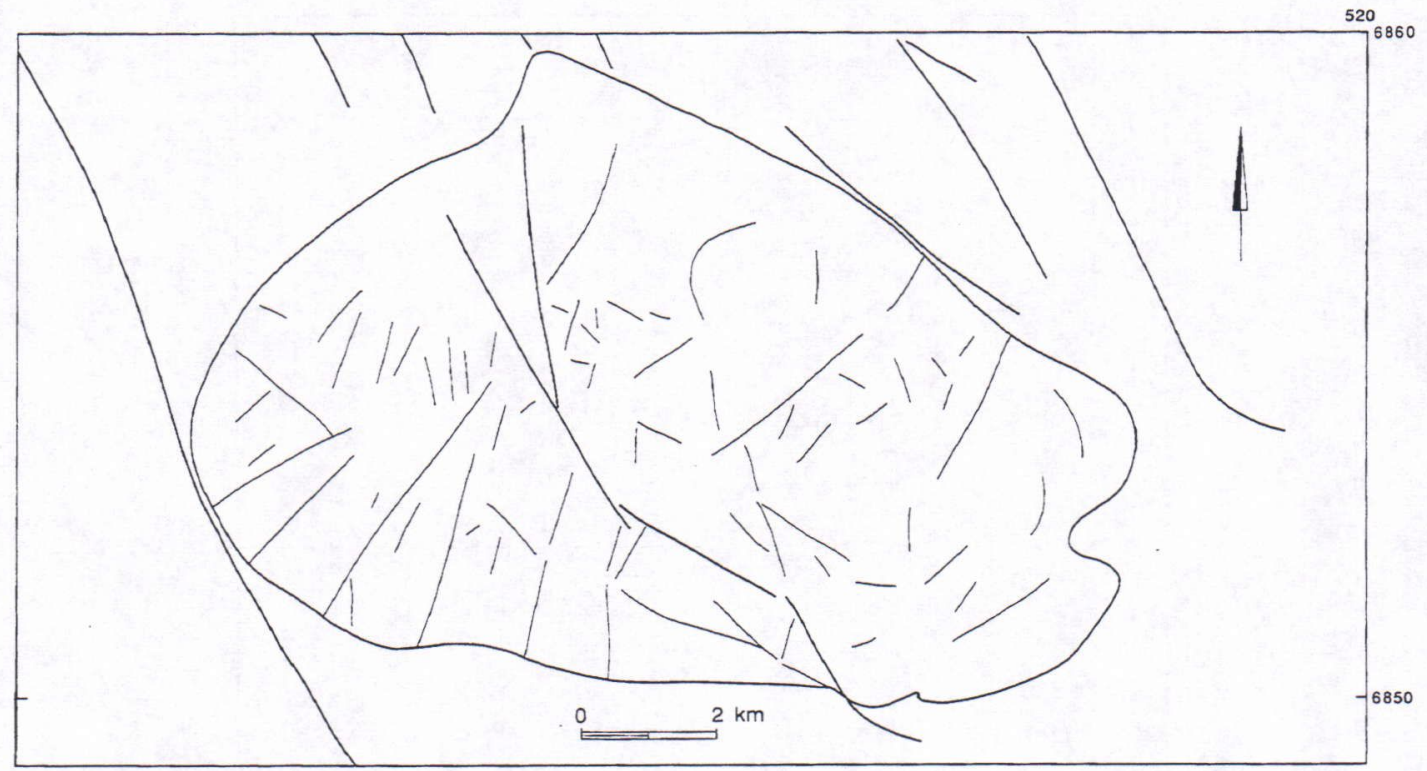

Figure 5. Fracture map of the Orivesi granite batholith. The map is based on field observations by the first author, and on interpretation from topographical maps, the map of surficial deposits (Kujansuи et al. 1981), Laitakari (1986) and Sjöblom (1990).

lineation can be measured on the foliation surfaces (root zone of Vigneresse 1995). This half is composed of almost pure Orivesi granite with widely spaced fracturing. In contrast, the eastern half is characterized by a slightly larger diameter and by the presence of Särkijärvi late-fraction granite together with numerous aplitic sheets and dykes. The aplite sheets conceivably represent late magmatic fillings of fractures in the upper parts of the batholith. The foliation is less well developed and dips gently in the central-eastern parts of the batholith. Concordant gently dipping schist inclusions occur in the eastern half of the batholith. The density of the late fractures in outcrops is high.

The present deposits of dimension stone and potential future sites are in the western half of the Orivesi granite batholith, where the rock as a whole is more homogeneous and less fractured. The structural differences in the two halves of the batholith can be explained as representing different crustal levels caused by a west-side-up movement along the sheared and later crushed fault zone in the middle of the batholith (fig. 6B).
The structures in the subvertical fault zone indicate a series of movements starting with intrusion of an aplitic residual melt into fractures in semi-crystallized Orivesi granite magma with subsequent subvertical ductile deformation of the aplite granite, continuing in a more brittle fashion and producing contemporaneous subhorizontal comb fractures and subvertical slip-parallel fractures (Stewart \& Hancock 1990) later filled with quartz and finally resulting in a division of the batholith into two halves. The concentric foliation in the western half dips $60^{\circ}-80^{\circ}$ towards the centre of the batholith, while the foliation in the centraleastern half is more gently dipping. If we reconstruct a batholith with the slightly larger dimensions of the eastern half, and with contacts dipping $70^{\circ}$ inwards, we need to move the western part upwards about $1 \mathrm{~km}$ along the central fault zone to reconstruct the present outlines of the batholith. The uplift has probably not been uniform, since the difference in the structures across the fault is more marked in the northern-central parts of the batholith than in the southern parts. Repeated subvertical 


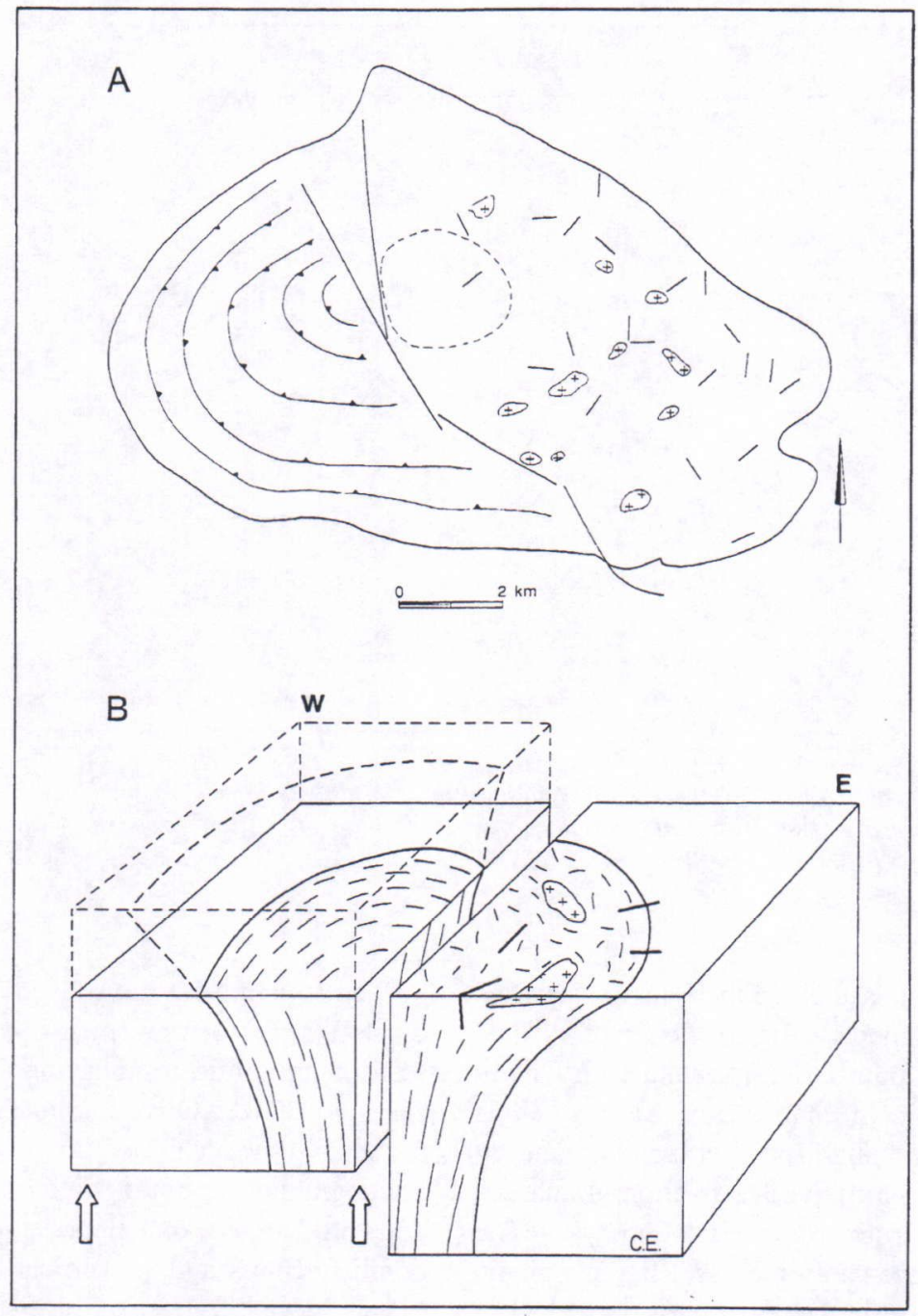

Figure 6. The different structural characteristics of the two halves of the Orivesi granite batholith (see text) indicate that they represent different erosional levels caused by a west-side-up movement. A. Simplified geological map of the Orivesi granite batholith (cf. fig. 2 and 3). B. A 3D model of the effect of the west-side-up faulting. Not to scale.

movements along the lineaments in the southern part of the CFGC can be observed in outcrops as mylonites and shear zones with subvertical linear structures. A component of dextral lateral movement along the lineaments can be interpreted from the aeromagnetic shaded maps. This dextral component of lateral movement along regional shear zones agrees with the subvertical component of west-side-up movement between the halves of the Orivesi batholith.

The structures in both halves of the Orivesi granite batholith are mainly of magmatic origin and emplacement-induced. The magmatic foliation all over the batholith is concentric with its 
margins. At the exposed contacts the ductile structures in the host rocks are parallel to the batholith. The eastern and western contacts are not exposed. Neither the schistosity nor the foliation of the host rocks extends into the marginal parts of the batholith, which indicates that the batholith is not affected by the ductile deformation that produced the structures in the host rocks. The Orivesi granite is intrusive into, and relatively younger than, the host rocks. This is also shown by the inclusions and xenoliths of foliated granodiorites and earlier deformed schists in the granite. The porphyritic granitic veins cut the main $\mathrm{S} 1$ schistosity in the schists at the southern contact. The batholith is almost unaffected by regional ductile deformation. Late semi-brittle movements along aplites and later shear bands deform both the batholith and the host rocks. The Orivesi granite shares much of its structural character and magmatic internal structures with the neighbouring Juupajoki granite (Sjöblom 1990; Selonen 1991; Lahtinen 1994). The Juupajoki granite, together with the $1876 \pm 7 \mathrm{Ma}$ old Puula granite (Nironen 1995), gives slightly younger ages than the other granitoids in the CFGC: $1879 \pm 14 \mathrm{Ma}$ (Patchett \& Kouvo 1986) and $1880 \pm 16$ (Sjöblom 1990; cf. Lahtinen 1994); and even if the Orivesi granite has less obviously crosscutting contacts than the Juupajoki granite (Laitakari 1986; Sjöblom 1990), they can be correlated on structural grounds and considered coeval in time. The Orivesi granite should thus be regarded as post-tectonic in relation to the ductile structures in the host rocks, conceivably belonging to the $\sim 1.87 \mathrm{Ga}$ old suite of granites described by Rämö \& Nironen (1995). This study corroborates the concept of a diversity of CFGC-granitoids with different structural features, ages and contact relations and indicate different active periods of magmatism in time in the CFGC (cf. Lahtinen 1994; Rämö \& Nironen 1995; Nironen 1995).

Several structural features indicate that the intrusion of the Orivesi granite batholith has been diapiric, at least during the final stages of the emplacement. The concentric and emplacement-induced foliation, the concordant and inward-dipping contacts and the mainly flattening-type strain in the Orivesi granite batholith, as well as the growing intensity of the magmatic foliation against the margins of the batholith, the semi-radial local fracture pattern (emplacement fractures) in the western part of the batholith and the parallel ductile structures in the host rocks against the batholith, indicate diapiric emplacement associated with minor lateral push (eg. Bateman 1984; Castro $1984 ; 1987)$. The subvertical lineation on the foliation surfaces in the Orivesi granite results from subvertical movement of a crystal mush-type magma, but the weak intensity of the lineation suggests diapirism during final emplacement rather than long-distance diapiric ascent of the magma. In the latter case the linear structural element should be stronger (cf. Bateman 1984). The contacts and the scarcity of host rock xenoliths indicate that the stoping mechanism has played an insignificant part in the emplacement of the batholith, but according to Paterson \& Vernon (1995) the stoped fragments can be swept away along a downgoing stream of magma close to the margins. The northeastern contact of the Orivesi granite batholith is rectilinear following a fault/fracture zone, indicating tectonic control of the emplacement of the batholith. The Orivesi granite batholith together with the Juupajoki and Kuru batholiths are spatially closely related to a series of NW-SE trending regional shear zones on a scale of tens of kilometres at the southern margin of the CFGC. The granitoids are restricted to an intersection between the shear zones and a E-W trending magnetic anomaly (cf. Lahtinen 1994). According to Lahtinen (1994) the anomaly reflects a mafic underplating, giving rise to the high- $\mathrm{K}$ granite magmas in the southern part of the CFGC. The shear zones provide regional tectonic control for the ascent and emplacement of the magmas. The importance of deep shear zones in the crust as conduits for granitic melts has been pointed out by i.a. Bateman (1984; 1985), Clemens \& Mawer (1992) and Petford et al. (1993). The crustal discontinuities may inherit from the previous stacking and thickening processes in this part of the Svecofennian domain (Korja 1995). According to Lahtinen (1994), Korja (1995) and Rämö \& Nironen (1995) the earlier compressional stress field has later changed into an extensional one. The shear zone 
control of the emplacement of the Orivesi granite batholith shows that during the time of the intrusion ( 1.87 Ga ago) an extensional tectonic regime has been prevalent, at least in the vicinity of the regional shear zones in the southern part of the CFGC. At the same time compression dominates in the Svecofennian domain further south (Ehlers et al. 1993).

\section{CONCLUSIONS}

We conclude the findings of the structural analysis of the Orivesi granite batholith as follows. The batholith is divided into two halves by a fault. The western half has moved upwards, exposing different structural levels in the batholith halves on the present surface. This difference in tectonic level controls the location of good dimension stone areas to the western half. The Orivesi granite batholith (as well as the Juupajoki and the Kuru batholiths) has intruded along the regional NW-SE trending shear zones in the southern part of the CFGC. The emplacement has been diapiric at least during the final stages of the emplacement. The structures in the whole
Orivesi granite batholith are magmatic and induced by diapiric emplacement. The regional ductile deformation has had a negligible effect on the Orivesi granite and we conclude that the granite should be regarded as post-tectonic in relation to the deformed host rocks. The intrusion of the granites along the regional shear zones shows that extensional tectonism was in action in the proximity of the zones at the southern margin of the CFGC during the emplacement of the granitoids. The extensional episode has locally outlasted the crystallisation of the Orivesi granite as shown by the brittle steep faulting in the Orivesi granite batholith.

ACKNOWLEDGEMENTS: The study was supported financially by the K.H. Renlund Foundation which is gratefully acknowledged. Merja Kuusisto prepared the line drawings and Veikko Grönroos the thin sections. Christopher Grapes corrected the language. The Defence Forces of Finland, specially Samuli Suokas, is thanked for the smooth arrangement of accommodation for the first author in Lyly, Juupajoki during the field work. 


\section{REFERENCES}

Aho, L. 1979. Petrogenetic and geochronological studies of metavolcanic rocks and associated granitoids in the Pihtipudas area, Central Finland. Geol. Surv. Finland, Bull. 300. 22 pp.

Aurola, E. 1967. Building stones of Kuru, Finland. Geol. Surv. Finland. Geoteknillisiä julkaisuja N:o 71. (Geotech. publ. Nr 71). 64 pp. (In Finnish with English summary).

Bateman, R. 1984. On the role of diapirism in the segregation, ascent and final emplacement of granitoid magmas. Tectonophysics, 110, 211-231.

Bateman, R. 1985. Aureole deformation by flattening around a diapir during in situ ballooning: The Cannibal Creek granite. J. Geol. 93, 293-310.

Bergman, L. 1986. Structure and mechanism of intrusion of postorogenic granites in the archipelago of southwestern Finland. Acta Academiae Aboensis, Ser. B. Vol. $46 \mathrm{nr} 5.74 \mathrm{pp}$.

Castro, A. 1984. Emplacement fractures in granite plutons (Central Extremadura batholith, Spain). Geol. Rundschau 73. 869-880.

Castro, A. 1987. On granitoid emplacement and related structures. A review. Geol. Rundschau 76. 101-124.

Clemens, J.D. and Mawer, C.K. 1992. Granitic magma transport by fracture propagation. Tectonophysics, 204, 339-360.

Ehlers, C. and Bergman, L. 1984. Structure and mechanism of intrusion of two postorogenic granite massif, southwestern Finland. In A. Kröner and R. Greiling (eds): Precambrian Tectonics Illustrated. E. Schweizerbart'sche Verlagsbuchhandlung (Nägele u. Obermiller). Stuttgart, Germany. 173-190.

Ehlers, C., Lindroos, A. and Selonen, O. 1993. The late Svecofennian granite-migmatite zone of southern Finland - a belt of transpressive deformation and granite emplacement. Precambrian Res., 64, 295-309.

Flinn, D. 1965. On the symmetry principle and the deformation ellipsoid. Geol. Mag. 102, 36-45.

Front, K. and Nurmi, P.A. 1987. Characteristics and geological setting of synkinematic Svecokarelian granitoids in southern Finland. Precambrian Res., $35,207-224$.

Huhma, H. 1986. Sm-Nd, U-Pb and $\mathrm{Pb}-\mathrm{Pb}$-isotopic evidence for origin of the early Proterozoic Svecokarelian crust in Finland. Geol. Surv. Finland, Bull. 337. 52 pp.
Kallio, J. 1983. Den porfyriska granodioriten i Joutsa, dess intrusionsmekanism och tektoniska ställning. (The porphyritic granodiorite in Joutsa, its intrusion mechanism and tectonic position). Unpublished $\mathrm{Ph}$. Lic. thesis. Åbo Akademi University. Department of geology and mineralogy. $73 \mathrm{pp}$. (In Swedish).

Kallio, J. 1986. Pre-Quaternary rocks of the Joutsa map-sheet area. Geological map of Finland 1:100 000. Explanation to the maps of Pre-Quaternary rocks, sheet 3122 Joutsa. Geological Survey of Finland. 56 pp. (In Finnish with English summary).

Korja, A. 1995. Structure of the Svecofennian crust - growth and destruction of the Svecofennian orogen. Institute of Seismology, University of Helsinki, Report S-31. 36 pp.

Kujansuu, R. (ed.), Erviö, R., Herola, E., Hyyppä, J., Kae, E., Lahermo, P., Raikamo, E., Stén, C-G. and Taka. M. 1981. Surficial deposits in the Orivesi area. Explanation to the maps of surficial deposits, sheets 2142 01-12 (1:20 000). Geological Survey of Finland. 44 pp. (In Finnish with English summary).

Laitakari, I. 1986. Geological map of Finland. PreQuaternary rocks. 1:100 000. Sheet 2142 Orivesi. Geological Survey of Finland.

Lahtinen, R. 1994. Crustal evolution of the Svecofennian and Karelian domains during 2.1-1.79 Ga, with special emphasis on the geochemistry and origin of 1.93-1.91 Ga gneissic tonalites and associated supracrustal rocks in the Rautalampi area, central Finland. Geol. Surv. Finland, Bull. 378, $128 \mathrm{pp}$.

Nironen, M. 1989. Emplacement and structural setting of granitoids in the early Proterozoic Tampere and Savo Schist Belts, Finland - implications for contrasting crustal evolution. Geol. Surv. Finland, Bull. 346, 83 pp.

Nironen, M. 1995. Block boundary at the southeastern margin of the Paleoproterozoic Central Finland Granitoid Complex. Geol. Surv. Finland, Bull. 382, 91-115.

Nironen, M. and Csongrádi, J. 1984. Charasteristics of the Proterozoic porphyry-type $\mathrm{Cu}$ occurrence at Tienpää, Halsua, western Finland. Bull. Geol. Soc. Finland 56, 89-97.

Nironen, M. and Bateman, R. 1989. Petrogenesis and syntectonic emplacement in the early Proterozoic of south-central Finland: a reversely zoned dioritegranodiorite and a granite. Geol. Rundschau 78/2, 617-631. 
Nironen, M. and Front, K. 1992. The $1.88 \mathrm{Ga}$ old Mäntylä complex, central Finland: emplacement and deformation of mafic to felsic plutonic rocks and assiciated Mo mineralisation. Bull. Geol. Soc. Finland 64, 75-90.

Nurmi, P.A and Haapala, I. 1986. The Proterozoic granitoids of Finland: Granite types, metallogeny and relation to crustal evolution. Bull. Geol. Soc. Finland 58, 203-233.

Nurmi, P.A., Front, K., Lampio, E. and Nironen, M. 1984. Svecokarelian porphyry-type molybdenum and copper occurrences in southern Finland: their granitoid host rocks and lithogeochemical exploration. Geol. Surv. Finland. Rep. of inv. 67. 88 pp. (In Finnish with English summary).

Patchett, J. and Kouvo, O. 1986. Origin of continental crust of 1.9-1.7 Ga age: Nd isotopes and U-Pb zircon ages in the Svecokarelian terrain of South Finland. Contrib. Mineral. Petrol. 92, 1-12.

Paterson, S.R. and Vernon, R.H. 1995. Bursting the bubble of ballooning plutons: A return to nested diapirs emplaced by multiple processes. Bull. Geol. Soc. Am., v. 107, 1356-1380.

Petford, N., Kerr, R.C. and Lister, J.R. 1993. Dike transport of granitoid magmas. Geology, v. 21, 845-848.

Rämö, O.T. and Nironen, M. 1995. Petrogenesis of a $1.87 \mathrm{Ga}$ post-tectonic bimodal granite suite in the Central Finland Granitoid Complex: The end of an orogenic cycle. In T. Kohonen and B. Lindberg (eds.): The 22 nd Nordic Geological Winter Meeting. 8-11 January 1996 in Turku - Åbo, Finland. Abstracts. Åbo Akademis Tryckeri, Turku, Finland. 181.
Selonen, O. 1991. K.H. Renlundin säätiön rakennuskivitutkimukset Oriveden ja Juupajoen porfyyrigraniittialueilla Pohjois-Hämeessä 1986 ja 1991 - yhteenveto. (Dimension stone investigations by the K.H. Renlund Foundation in the areas of the porphyritic granites in Orivesi and Juupajoki in northern Häme 1986 and 1991 - summary). Unpublished report. K.H. Renlund Foundation. Åbo Akademi University. Department of geology and mineralogy. Turku. 27 pp. (In Finnish).

Selonen, O. 1994. Granittektonik och prospektering av byggnadssten - exempel från södra Finland. (Granite tectonics and exploration of dimension stone - examples from southern Finland). Unpublished $\mathrm{Ph}$. Lic. thesis. Åbo Akademi University. Department of geology and mineralogy. Turku. 122 pp. (In Swedish).

Simonen, A. 1980. The Precambrian of Finland. Geol. Surv. Finland, Bull 304. 58 pp.

Sjöblom, B. 1990. Pre-Quaternary rocks of the Mänttä map-sheet area. Geological map of Finland 1:100 000. Explanation to the maps of Pre-Quaternary rocks, sheet 2231 Mänttä. Geologcal Survey of Finland. 64 pp. (In Finnish with English summary).

Stewart, I.S. and Hancock, P.I. 1990. Brecciation and fracturing within neotectonic normal fault zones in the Aegean region. In R.J. Knipe and E.H. Rutter (eds): Deformation mechanisms, rheology and tectonics. Geological Society Special Paper Publication No. 54, 105-110.

Vigneresse, J.L. 1995. Control of granite emplacement by regional deformation. Tectonophysics 249 , 173-186. 